$\underline{\text { Review Article }}$

\title{
PHARMACOLOGY OF NOVAL CANNABINOIDS
}

\author{
SUMITHA S. K. , VEENA S. PATTAMMADY ${ }^{1}$, R. SAMBATHKUMAR ${ }^{2}$
}

${ }^{*}$ Department of Pharmacy Practice, J. K. K. Nattraja College of Pharmacy, Erode, India, 1J. K. K. Nattraja College of Pharmacy, Erode, India, 2Department of Pharmaceutics, J. K. K. Nattraja College of Pharmacy, Erode, India

Email: sumitha94pharm.d@gmail.com

Received: 08 Oct 2019, Revised and Accepted: 28 Nov 2019

\section{ABSTRACT}

Cannabis is a plant rich in various compounds that have a variety of impacts on the physiology of humans and the effects of these metabolites have a significant role in managing a variety of clinical diseases. A substantial increase in the use of SC (synthetic cannabinoids) had seen in the last few years especially infrequent cannabis users. The SCs will generate psychoactive effects that were similar to cannabis. However, the composition and pharmacological characteristics of these drugs make them possibly hazardous.

Like all drugs, cannabis' pharmacokinetics depends on the route of administration. Several studies showed that the bioavailability is less in oral administration when compared to inhalation. The main reason for this decrease in oral bioavailability is that cannabinoids undergo the first-pass metabolism before entering into the systemic circulation whereas in inhalation, it enters the circulation directly through the lungs.

Cannabis sativa is a psychoactive plant that contains more than 500 components of which 104 cannabinoids had been identified. Of these, 2 components such as $\triangle^{9}$-THC ( $\triangle^{9}$-tetrahydrocannabinol) and $C B D$ (cannabidol) were under the scientific investigation. $\triangle^{9}$-THC is the primary cannabinoid which was responsible for the consequences of psychotrophy. The potency of cannabis is assessed based on the THC concentration of a sample that is the main psychoactive cannabinoid in cannabis. The adverse effects are in direct relation to the concentration of $T H C$ in the product after regular cannabis use. It can be assumed that several cannabinoids will find their way into the pharmacies from preclinical research within a century.

Keywords: Cannabis sativa, Synthetic cannabinoids, $\triangle^{9}-T H C, C B D$, Psychoactive effects

(c) 2020 The Authors. Published by Innovare Academic Sciences Pvt Ltd. This is an open access article under the CC BY license (http://creativecommons.org/licenses/by/4.0/) DOI: http://dx.doi.org/10.22159/ijpps.2020v12i1.36005. Journal homepage: https://innovareacademics.in/journals/index.php/ijpps

\section{INTRODUCTION}

Cannabis sativa (also called marijuana) is a psychoactive plant that contains more than 500 components of which 104 cannabinoids had been identified [1]. Of these, 2 components such as $\triangle^{9}-T H C$ and $C B D$ were under scientific investigation to their pharmacological properties $[1,2] . \Delta^{9}-T H C$ is the primary cannabinoid that was responsible for consequences of psychotrophy [3]. It interacts with and activates G protein-coupled $\mathrm{CB}_{1}$ and $\mathrm{CB}_{2}$ cannabinoid receptors [4].

In the $1930 \mathrm{~s}$ and $40 \mathrm{~s}$ the chemical structure of the first phytocannabinoids was determined effectively [3]. Another scientific discovery in the cannabinoid research was the identification of the particular cannabinoid receptors system in mammals and their cannabinoid endogenous ligands [1, 3].

The potency of cannabis is assessed based on the concentration of a sample that is the main psychoactive cannabinoid in cannabis. The adverse effects are in direct relation to the concentration of THC in the product after regular cannabis use [2].

Several studies over the last few years had shown that $C B D$ levels may also have an important impact [5]. When compared to THC, it has a protective action against certain negative psychological effects and are also able to antagonize some of the undesired effects [2].

Various cannabis preparations are available on the illicit drug market and proper monitoring of those agents had helped scientists to evaluate the potency of products which is currently used [3]. Changes can then be compared with the prevalence of negative health consequences in users. Certain authors hypothesize that an increase in cannabis potency and in the ratio of the psychoactive component $\left(\Delta^{9}\right.$-THC) to CBD might be the reason behind the increasing harmful effects associated with cannabis use [3].

Moreover, a substantial increase in the use of SCs had seen in the last few years especially infrequent cannabis users [1]. The SCs will generate psychoactive effects that were similar to cannabis and are also readily acquired through normal screenings that are undetected. However, the composition and pharmacological characteristics of these drugs make them possibly hazardous [5].

\section{Cannabinoid receptors}

Two receptors of cannabinoids were recognized, The $\mathrm{CB}_{1}$ and the $\mathrm{CB}_{2}$ receptor had been identified as the 2 cannabinoid receptors and it exhibits $48 \%$ of the amino acid sequence [6].

In addition to their difference in amino acid sequence, they vary in signalling mechanisms, tissue distribution and sensitivity to certain agonists and antagonists showing marked selectivity for one or the other type of receptor [7]. Activation of cannabinoid receptors triggers adenylate cyclase inhibition, thus inhibiting the conversion of ATP to cyclic AMP [8].

$\mathrm{CB}_{1}$ receptors are widely expressed in basal ganglia, cerebellum, hippocampus and dorsal primary afferent spinal cord regions, reflecting the significance of the cannabinoid system in motor control, memory processing and pain modulation with low expression in the brain stem [7]. $\mathrm{CB}_{1}$ receptors are also found in endocrine glands, urinary and gastrointestinal tracts, spleen, leukocytes, heart and parts of the reproductive system [6].

$\mathrm{CB}_{2}$ receptors are seen primarily in immune cells, mainly in leukocytes, spleen and tonsils [9]. Immune cells also express $\mathrm{CB}_{1}$ receptors, but in the immune system, there is significantly more mRNA for $\mathrm{CB}_{2}$ than $\mathrm{CB}_{1}$ receptors. Modulation of cytokine release is one of the main tasks of CB receptors in the immune system [6].

$\mathrm{CB}_{1}$ receptor activation generates marijuana like impacts while $\mathrm{CB}_{2}$ receptor activation does not [10]. Selective $C_{3}$ receptor agonists have therefore become an increasingly researched target for therapeutic uses of cannabinoids [11].

Known cannabinoids and their effects on cellular and system physiology

In many tissues throughout the body, $\mathrm{CB}_{1}$ receptors are abundantly found in most of the brain areas and the peripheral nervous system 
[5]. They are also found in some non-neuronal organs such as the liver, stomach, heart, testes and fat tissues [8]. Presynaptic activation of $\mathrm{CB}_{1}$ receptors in neuronal tissue inhibits the release of neurotransmitters such as gamma-Aminobutyric acid and glutamate by releasing $\beta \gamma$-subunits from the $\mathrm{G}$ protein complex, resulting in inhibition of voltage-gated calcium channels and vesicle release [12].

While $\mathrm{CB}_{1}$ receptor activation typically inhibits the release of neuronal transmitters, in vivo activation of $\mathrm{CB}_{1}$ with $\Delta^{9}-T H C$ has been noted to occasionally boost the release of acetylcholine, dopamine and glutamate in different brain areas of rats [13].

This is probably due to selective antagonism by $\Delta^{9}-T H C$ of endocannabinoids, as stated by Patel and Hillard [14] when antianxiolytic effects of $\Delta^{9}$-THC administration in mice were observed. However, cannabidiol does not share psychotropic activity with $\Delta^{9}$. $T H C$, but acts as an inverse agonist or even antagonist of $\mathrm{CB}_{1}$ and thus attenuates in vivo response to $\triangle^{9}-T H C$ in various model species [15]. On the other side, cannabinoid $\mathrm{CB}_{2}$ receptors are more commonly found in immune related organs and attenuate pro- inflammatory reactions such as cytokine release and immune cell response when it gets activated [16]. There is proof that CBD interacts as an inverse agonist with $\mathrm{CB}_{2}$ receptors resulting in a welldocumented decrease of clinical pro inflammatory markers such as TNF $\alpha$, iNOS and COX-2 expression [17]. In relation to the impacts on $\mathrm{CB}_{2}$, $\mathrm{CBD}$ also interacts with receptors related to the immune system [18]. $\mathrm{CB}_{2}$ receptors are also found in reduced concentrations in both brain and peripheral neuronal tissue compared to $\mathrm{CB}_{1}$ receptors, but their function has not yet been elucidated [19].

\section{Pharmacokinetics of cannabis-based on route of administration}

Like all drugs, cannabis' PK (pharmacokinetics) depends on the route of administration most of the human clinical trial have assessed the cannabis PK activity following inhalation or ingestion [20]. While various trials report a broad variety of PK parameters due to variations in dosage, it remains apparent that the onset, absorption rate and bioavailability of $T H C$ and $C B D$ after inhalation are considerably greater than after ingestion or oral administration [21].

Table 1: Pharmacokinetics of cannabis based on route of administration

\begin{tabular}{lll}
\hline Route of administration & Inhalation & Oral \\
\hline \% Dose Consumed & $\sim 50 \%$ (loss due to pyrolysis) & $100 \%$ \\
Trajectory to Circulation & Lungs-Bronchi-Bronchiole-Alveoli & Stomach-Small Intestines-Portal Vein-Liver \\
Other Factors Affecting Uptake & Intake upon inhalation (puff duration, & Absorption (stomach contents, metabolic rate, genetic variants in CYP \\
& intake volume, holding time) & 450 enzyme activity, enzyme regulation by other drugs) \\
First-Pass Hepatic Metabolism & Bypassed & First-Pass Hepatic Metabolism by CYP450 enzymes \\
Bioavailability & $2-56 \%$ & $<20 \%$ \\
Onset & Immediate & $30-90$ min \\
Time of Peak Plasma & $5-10$ min & $1-6 \mathrm{~h}$ \\
Duration & $2-4 \mathrm{~h}$ & $4-8 \mathrm{~h}$ \\
\hline
\end{tabular}

THC can be detected in the blood almost instantly after smoking and maximum plasma levels can be measured after 5-10 min [22]. The reported peak values differ with the dose given. For example, one research revealed that cigarette inhalation comprising $1.75 \% \mathrm{THC}$ (equal to $16 \mathrm{mg}$ THC) and $3.55 \%$ THC (34 mg THC) resulted in mean plasma peak levels of $84.3 \mathrm{mg} / \mathrm{ml}$ and $162.2 \mathrm{mg} / \mathrm{ml}$ respectively [20]. However, the range of maximum plasma levels measured for the low dose cigarette was $50-129 \mathrm{mg} / \mathrm{ml}$ and the high dose cigarette was 76-267 mg. ml.

When comparing reported bioavailability values such broad ranges are also discovered. In some research, the bioavailability of inhaled THC was recorded as 30\%, 10-35\%and 18\% [23-25]. One research comparing THC's pharmacokinetics between regular and occasional users found that bioavailability was $23-27 \%$ for regular users and $10-14 \%$ for occasional users [26]. These variations arise from the difference in smoking techniques with variables such as puff length, quantity of intake and holding time to determine medication consumption [27].

Fewer studies concentrated solely on CBD's PK activity. One research revealed that the bioavailability of $C B D$ after inhalation was $31 \%$, while others commented on the resemblance between $T H C$ and $C B D$ in PK activity. It has been noted, however, that $C B D$ may change $T H C$ 's PK activity and may mediate some of its adverse effects, such as paranoia and anxiety [28]. The precise reason for this modulatory impact is unknown, but the present scientific opinion is that $C B D$ inhibits cytochrome P450 enzyme activity, which in turn affects THC metabolism especially after oral administration [29].

The main reason for this decrease in oral bioavailability is that cannabinoids undergo comprehensive first-pass metabolism with CYP 450 genes before systemic circulation is achieved [20].

With an inhalation, first-pass metabolism is prevented, as cannabinoids enter the circulation through the lungs [20].

\section{Synthetic cannabinoids}

When scientists first explored the endocannabinoid system and tried to create new medicines for cancer pain, SCs appeared in the 1970s. SC emerged on the illegal drug market around the year 2000, where there prevalence was underestimated for a long time [30]. Since then their market place has risen steadily. The illicit market has recognized more than 560 synthetic psychoactive substances. In the last $5 \mathrm{y}$, there has been a steep increase with the appearance of 380 fresh synthetic drugs [31]. More than 160 SCs have been recognised in different products since 2008. Most SCs are produced by Asian based chemical companies [32].

The rise in consumption of SCs was particularly remarkable compared to other new drugs on the market [33]. In general, these products are provided as herbal blends. Tablets, capsules or powders can also be purchased [34]. They are often smoked by pipe or as a joint [35]. Newer liquid formulations have recently emerged which can be vaporized by electronic cigarette [36].

The pharmacological characteristics of SCs are distinct from cannabis. This particular lipophilic [37] molecules are complete $\mathrm{CB}_{1}$ (CBD receptor 1 ) and $\mathrm{CB}_{2}$ (CBD receptor 2 ) agonists. Their potential binding affinity to these receptors is also much greater than that of $T H C$, resulting in significantly greater psychoactive effects [38].

SC effects depend on the type of product used and its dose. Similarly, the pharmacokinetics depends on the administration route. In some cases the onset of psychoactive effects and physical symptoms begins a few minutes after smoking [39]. The effects are comparable to those observed after high doses of THC.

Anxiety is frequently reported. Some users have described feeling limited in their movements, whereas no motor deficits are objectively observed. On average, the effects last for about $6 \mathrm{~h}$, steadily decreasing until the next day [40-42].

\section{Endocannabinoids}

Following the identification of cannabinoid receptors, endogenous ligands were detected for these receptors, called endocannabinoids, a family of eicosanoids [43]. There were 5 recognised endocannabinoids. These are $N$-arachidonylethanolamide (anandamide), 2-AG (2-arachidonylglycerol), 2-arachidonylglyceryl ether (noladin ether), O-arachidonyl-ethanolamine (virodhamine), and NADA (N-arachidonyl-dopamine) [44-47]. 
Cannabinoid receptors and their endogenous ligands are the cannabinoid system found in mammals and many other species, which is teleologically millions of years old [48]. Endocannabinoids serve as neurotransmitters or neuromodulators [49]. Anandamide and NADA not only bind to cannabinoid receptors, but also activate VRI (vanilloid receptors) and selective ion channels associated with hyperalgesia $[44,50]$.

The endocannabinoids are produced on demand by cleavage of membrane lipid precursors and released in a stimulus dependent manner from cells [51]. They are quickly deactivated by absorption into cells and metabolized after its release [52, 53].

\section{Therapeutic uses}

Many illness have been treated with cannabis preparations. In addition to phytocannabinoids, several synthetic cannabinoid derivatives and modulation of the endocannabinoid system are under clinical investigation that are devoid of psychotropic effects [54].

Therapeutic effects can be designed as: 1) clinically, established, 2) clinically relatively well-confirmed, 3) clinically less confirmed.

\section{Established effects}

Marinol (dronabinol, $\Delta^{9}-T H C$ ) is approved for medical use in HIV/AIDS patients, with refractory nausea and vomiting induced by antineoplastic medicines used for cancer therapy and loss of appetite [55]. This impacts can be considered as established effects for THC and cannabis. THC is also efficient in ipecac syrup induced cancer cachexia and nausea. Cesamet (nabilone) is approved for cancer chemotherapy related nausea and vomiting [56].

\section{Relatively well-confirmed effects}

In recent years there is also increasing evidence for therapeutic effects of THC and cannabis extracts in spasticity due to multiple sclerosis and spinal cord injury, chronic pain and Tourette's syndrome [57]. Effects in some other movement disorders (including dystonia and levodopa-induced dyskinesia), in asthma and glaucoma can also be regarded as relatively well-confirmed effects with small placebo controlled trials demonstrating benefits. However, results were sometimes conflicting [58].

\section{Less confirmed effects}

There are several indications, in which mainly case reports suggest benefits [59]. These are allergies, inflammation, epilepsy, intractable hiccups, depression, bipolar disorders, anxiety disorders, addiction to opiates and alcohol, withdrawal symptoms, and disturbed behaviour in Alzheimer's disease [60].

\section{Pharmacological effects of other cannabinoids}

$C B D$ is a non-psychotropic cannabinoid that has been shown to have sedative, anti-epileptic, anti-dystonic, anti-emetic and antiinflammatory impacts. It decreases intraocular pressure, has been neuroprotective and has antagonised THC's psychotropic and several other effects. In psychiatry, anxiolytic and anti-psychotic characteristics may be helpful [60].

\section{Central nervous system and neurochemistry}

Cannabinoids interact with a multitude of neurotransmitters and neuromodulators, such as acetylcholine, dopamine, GABA $(\gamma-$ aminobutyric acid), histamine, serotonin, glutamate, norepinephrine, prostaglandins and opioid peptides [42].

Cannabinoids influence the activity of most neurotransmitters in a complex manner, which sometimes may result in contradictory effects with suppression or induction/intensification of seizures, emesis, pain and tremor depending on subject and condition [42].

\section{Circulatory system}

THC may be lead to tachycardia [61] and increase cardiac output with enhanced cardiac labour and demand for oxygen [62]. It can also produce peripheral vasodilation and orthostatic hypotension. Tachycardia by THC may easily be explained by vagal inhibition [63]. Regular use can lead to bradycardia [64].

\section{Some other organ systems and effects}

\section{Bone formation}

Preliminary observations show that endocannabinoids seem to stimulate bone formation [65].

\section{Cancer}

Cannabinoid agonists inhibited in vitro the proliferation of human breast cancer cells, and directly applied at the tumour site, showed antineoplastic activity against malignant gliomas [66, 67].

\section{Digestive tract}

Cannabinoid agonists inhibit gastrointestinal motility and gastric emptying in rats [68]. THC has induced a substantial delay in gastric emptying in a research with humans [69]. Furthermore, CB agonists inhibited rat's secretion of gastric acid induced by pentagastrin [70].

\section{Eye}

The proof of cannabinoid receptors at various locations (anterior eye, retina and corneal epithelium) indicates that cannabinoids regulates various physiological functions in the human eye [71]. Vasodilation in the eye is noted after expose to THC as a conjunctival reddening. THC and some other cannabinoids reduce intraocular pressure [71]. $\mathrm{CB}_{1}$ receptors in the eye are involved in this effect while intraocular pressure is not reduced by $\mathrm{CB}_{2}$ receptor agonists [72].

\section{Toxicity}

There was no substantiation of acute deadly instances in humans. However, $T H C$ can trigger myocardial infarction owing to circulation impacts $[33,34]$. This is unlikely to occur in healthy individuals, but in people with heart disease who may at danger for orthostatic hypotension or elevated heart rate.

It is controversial whether heavy periodic consumption can lead to long term cognition impairment [35-37]. But irreversible impairment appears to be minimal if it occurs. Early users who begin their use before the age of 17 had poorer cognitive performance, particularly verbal IQ compared to users who begin later or non-users [38].

There is conflicting evidence that infants exposed to $T H C$ in utero suffer from developmental and cognitive impairment [39]. In vulnerable people, marijuana can induce schizophrenic psychosis and there is increasing evidence that there is a distinct cannabis psychosis.

\section{Tolerance and dependence}

Tolerance develops to most of the effects of THC causing changes in endocannabinoid formation and brain content $[73,59]$. Cannabinoid use has been shown to replace increased heart rate to normal or slow heart rate and it also results in orthostatic hypotension [55, 60]. Tolerance can be linked primarily to modify the pharmacodynamics, probably based on receptor down regulation and desensitization of the receptor [74].

After abrupt cessation of chronic dosing with elevated doses of THC, withdrawal was noted in humans [75]. Subjects complaint of internal disturbances, irritability, insomnia and reported hot flashes, sweating, rhinorrhoea, loose stools, hiccups and anorexia [76]. Symptoms of withdrawal are generally mild in humans and the risk of physical and psychological dependence is small compared to opiates, tobacco, alcohol and benzodiazepines [56-58].

\section{CONCLUSION}

Cannabis is a plant rich in various compounds that has a variety of impacts on the physiology of humans. These impacts are described mainly to cannabinoids and terpenes, large metabolite families that can interact with many of the body's cellular and physiological processes. While much studies are still remains to be done, the effects of these metabolites are a significant tool for managing a variety of clinical diseases.

Various concentrations of these compounds have distinct physiological impact and may affect the clinical utility based on how 
the plant is given to patients. It can be assumed that several cannabinoids and cannabinoid system modulations will find their way into the pharmacies from preclinical research within a century.

\section{FUNDING}

Nil

\section{AUTHORS CONTRIBUTIONS}

All the authors contributed equally.

\section{CONFLICTS OF INTERESTS}

\section{Declared none}

\section{REFERENCES}

1. Gaoni Y, Mechoulam R. Isolation, structure, and partial synthesis of an active constituent of hashish. J Am Chem Soc 1964;86:1646-7.

2. Ahmed SA, Ross SA, Slade D, Radwan MM, Khan IA, ElSohly MA. Structure determination and absolute configuration of cannabichromanone derivatives from high potency cannabis sativa. Tetrahedron Lett 2008;49:6050-3.

3. Pertwee RG. The central neuropharmacology of psychotropic cannabinoids. Pharmacother 1987;36:189-261.

4. Pertwee RG. Cannabis and cannabinoids: pharmacology and rationale for clinical use. Pharm Pharmacol Comm 1997;3:539-45.

5. Svizenskaa I, Dubovya P, Sulcovab A. Cannabinoid receptors 1 and 2 (CB1 and CB2), their distribution, ligands and functional involvement in nervous system structures-a short review. Pharmacol Biochem Behav 2008;90:501-11.

6. Pertwee RG. Sites and mechanisms of action. In: Grotenhermen F, Russo E. editors. Cannabis and cannabinoids. Pharmacology, toxicology, and therapeutic potential. Binghamton (NY): Haworth Press 2002;4:73-88.

7. Hanus L, Breuer A, Tchilibon S, Shiloah S, Goldenberg D, Horowitz $\mathrm{M}$, et al. HU-308: a specific agonist for $\mathrm{CB}$, a peripheral cannabinoid receptor. Proc Natl Acad Sci USA 1999;96:14228-33.

8. Cota D, Marsicano G, Tschop M, Grubler Y, Flachskamm C, Schubert $\mathrm{M}$, et al. The endogenous cannabinoid system affects energy balance via central orexigenic drive and peripheral lipogenesis. J Clin Invest 2003;112:423-31.

9. Sanchez C, de Ceballos ML, del Pulgar TG, Rueda D, Corbacho C, Velasco $\mathrm{G}$, et al. Inhibition of glioma growth in vivo by selective activation of the $\mathrm{CB}$ cannabinoid receptor. Cancer Res 2001;61:5784-9.

10. Devane WA, Hanus L, Breuer A, Pertwee RG, Stevenson LA, Griffin $\mathrm{G}$, et al. Isolation and structure of a brain constituent that binds to the cannabinoid receptor. Science 1992;258:1946-9.

11. Huang SM, Bisogno T, Trevisani M, Al-Hayani A, De Petrocellis L, Fezza F, et al. An endogenous capsaicin-like substance with high potency at recombinant and native vanilloid VR1 receptors. Proc Natl Acad Sci USA 2002;99:8400-5.

12. Blackmer T, Larsen EC, Bartleson C, Kowalchyk JA, Yoon E, Preininger AM, et al. G protein beta gamma directly regulates SNARE protein fusion machinery for secretory granule exocytosis. Nat Neurosci 2005;8:421-5.

13. Pertwee RG, Ross RA. Cannabinoid receptors and their ligands. Prostaglandins Leukot Essent Fatty Acids 2002;66:101-21.

14. Patel S, Hillard CJ. Pharmacological evaluation of cannabinoid receptor ligands in a mouse model of anxiety: further evidence for an anxiolytic role for endogenous cannabinoid signaling. J Pharmacol Exp Ther 2006;318:304-11.

15. Pertwee RG. The diverse CB1 and CB2 receptor pharmacology of three plant cannabinoids: $\Delta^{9}$-tetrahydrocannabinol, cannabidiol and $\Delta^{9}$-tetrahydrocannabivarin. $\mathrm{Br} \mathrm{J}$ Pharmacol 2008;153:199-215.

16. Cabral GA, Staab A. Effects on the immune system. Handb Exp Pharmacol 2005;168:385-423.

17. Castillo A, Tolon MR, Fernandez Ruiz J, Romero J, Martinez Orgado J. The neuroprotective effect of cannabidiol in an in vitro model of newborn hypoxic-ischemic brain damage in mice is mediated by $\mathrm{CB}_{2}$ and adenosine receptors. Neurobiol Dis 2010;37:434-40.
18. Carrier EJ, Auchampach JA, Hillard CJ. Inhibition of an equilibrative nucleoside transporter by cannabidiol: a mechanism of cannabinoid immunosuppression. Proc Natl Acad Sci 2006;103:7895-900.

19. Pertwee RG, Howlett AC, Abood ME, Alexander PH, Di Marzo V, Elphick MR, et al. Cannabinoid receptors and their ligands: beyond CB1 and CB2. Pharmacol Rev 2010;62:588-631.

20. Huestis MA. Human cannabinoid pharmacokinetics. Chem Biodivers 2007;4:1770-804.

21. Grotenhermen, Franjo. Pharmacokinetics and pharmacodynamics of cannabinoids. Anesthesiology 1997;86: 24-33.

22. Huestis MA, Henningfield JE, Cone EJ. Blood cannabinoids. I. absorption of THC and formation of 11-OH-THC and THCCOOH during and after smoking marijuana. J Anal Toxicol 1992;16:276-82.

23. Goulle J, Saussereau E, Lacroix C. Delta-9-tetrahydrocannabinol pharmacokinetics. Ann Pharm Francaises 2008;66:232-4.

24. Grotenhermen, Franjo. Pharmacokinetics and pharmacodynamics of cannabinoids. Anesthesiology 1997;86:24-33.

25. Mcpartland JM, Russo EB. Cannabis and cannabis extracts: greater than the sum of their parts? J Cannabis Therapeutics 2001;14:103-32.

26. Sharma P, Murthy P, Bharath MMS. Chemistry, metabolism, and toxicology of cannabis: clinical implications. Iran J Psychiatry 2012;7:149-56

27. Abramovici H. Information for health care professionals: cannabis (marihuana, marijuana) and the cannabinoids. Health Canada 2013;1:111-8.

28. Nadulski T, Pragst F, Weinberg G, Roser P, Schnelle M, Fronk $\mathrm{EE}$, et al. Randomized, double-blind, placebo-controlled study about the effects of cannabidiol (CBD) on the pharmacokinetics of delta9-tetrahydrocannabinol (THC) after oral application of THC verses standardized cannabis extract. Ther Drug Monit 2005;27:799-810.

29. Zhornitsky S, Potvin S. Cannabidiol in humans-the quest for therapeutic targets. Pharmaceuticals 2012;5:529-52.

30. Bachs L, Morland H. Acute cardiovascular fatalities following cannabis use. Forensic Sci Int 2001;124:200-3.

31. Mittleman MA, Lewis RA, Maclure M, Sherwood JB, Muller JE. Triggering myocardial infarction by marijuana. Circulation 2001;103:2805-9.

32. Pope HG Jr, Gruber AJ, Hudson JI, Huestis MA, Yurgelun Todd D. Neuropsychological performance in long-term cannabis users. Arch Gen Psychiatry 2001;58:909-15.

33. Pope HG Jr. Cannabis, cognition, and residual confounding. JAMA 2002;287:1123-31.

34. Solowij N, Stephens RS, Roffman RA, Babor T, Kadden R, Miller $\mathrm{M}$, et al. Cognitive functioning of long-term heavy cannabis users seeking treatment. JAMA 2002;287:1123-31.

35. Lyketsos CG, Garrett E, Liang KY, Anthony JC. Cannabis use and cognitive decline in persons under $65 \mathrm{y}$ of age. Am J Epidemiol 1999;149:794-800.

36. Fried PA, Watkinson B, Gray R. Differential effects on cognitive functioning in 9-to 12-year olds prenatally exposed to cigarettes and marihuana. Neurotoxicol Teratol 1998;20:293-306.

37. Solowij N, Grenyer BFS. Long term effects of cannabis on psyche and cognition. In: Grotenhermen F, Russo E. editors. Cannabis and cannabinoids. Pharmacology, toxicology, and therapeutic potential. Binghamton (NY): Haworth Press 2002;2:299-312.

38. Nunez LA, Gurpegui M. Cannabis-induced psychosis: a crosssectional comparison with acute schizophrenia. Acta Psychiatr Scand 2002;105:173-8.

39. Baker D, Pryce G, Giovannoni G, Thompson AJ. The therapeutic potential of cannabis. Lancet Neurol 2003;2:291-8.

40. Perez Reyes M. The psychologic and physiologic effects of active cannabinoids. In: Nahas G, Sutin KM, Harvey DJ, Agurell S. Marihuana and medicine. Totowa, NJ: Humana Press 1999;3:245-52.

41. Tashkin DP, Levisman JA, Abbasi AS, Shapiro BJ, Ellis NM. Short term effects of smoked marihuana on left ventricular function in man. Chest 1977;72:20-6. 
42. Shubhi R, Mohammed SQ, Deepak O. In vitro study of antiinflammatory and antioxidant activity of some medicinal plants and their interrelationship. Asian J Pharm Clin Res 2018;4:195202.

43. Neha C, Umar F, Mohammad AK. Efficacy of medicinal plants against human pathogens isolated from western himalayas of himachal pradesh. Asian J Pharm Clin Res 2017;9:353-7.

44. Hanus L, Abu-Lafi S, Fride E, Breuer A, Vogel Z, Shalev DE, et al. 2-arachidonyl glyceryl ether, an endogenous agonist of the cannabinoid CB1 receptor. Proc Natl Acad Sci USA 2001;98:3662-5.

45. Porter AC, Sauer JM, Knierman MD, Becker GW, Berna MJ, Bao J, et al. Characterization of a novel endocannabinoid, virodhamine, with antagonist activity at the CB1 receptor. J Pharmacol Exp Ther 2002;301:1020-4.

46. De Petrocellis L, Melck D, Bisogno T, Milone A, Di Marzo V. Finding of the endocannabinoid signalling system in Hydra, a very primitive organism: possible role in the feeding response. Neuroscience 1999;92:377-87.

47. Howlett AC. The cannabinoid receptors. Prostaglandins Other Lipid Mediat 2002;68:619-31.

48. Al-Hayani A, Wease KN, Ross RA, Pertwee RG, Davies SN. The endogenous cannabinoid anandamide activates vanilloid receptors in the rat hippocampal slice. Neuropharmacology 2001;41:1000-5.

49. Giuffrida A, Beltramo M, Piomelli D. Mechanisms of endocannabinoid inactivation: biochemistry and pharmacology. J Pharmacol Exp Ther 2001;298:7-14.

50. Di Marzo V. Endocannabinoids' and other fatty acid derivatives with cannabimimetic properties: biochemistry and possible physiopathological relevance. Biochim Biophys Acta 1998; 1392:153-75.

51. Dinh TP, Freund TF, Piomelli D. A role for monoglyceride lipase in 2-arachidonoylglycerol inactivation. Chem Phys Lipids 2002;121:149-58.

52. Walker JM, Huang SM, Strangman NM, Tsou K, Sanudo Pena MC. Pain modulation by release of the endogenous cannabinoid anandamide. Proc Natl Acad Sci USA 1999;96:12198-203.

53. Di Marzo V, Goparaju SK, Wang L, Liu J, Batkai S, Jarai Z, et al. Leptin-regulated endocannabinoids are involved in maintaining food intake. Nature 2001;410:822-5.

54. Roques B. Problems caused by the danger of drugs. Report of professor bernhard roques to the health minister. Paris 1998;3:52-60

55. Georgotas A, Zeidenberg P. Observations on the effects of four weeks of heavy marihuana smoking on group interaction and individual behavior. Compr Psychiatry 1979;20:427-32.

56. Anthony JC, Warner LA, Kessler RC. Comparative epidemiology of dependence on tobacco, alcohol, controlled substances, and inhalants: basic findings from the national comorbidity survey. Exp Clin Psychopharmacol 1994;2:244-68.

57. McPartland JM, Russo EB. Cannabis and Cannabis Extracts: greater than the sum of their parts? J Cannabis Ther 2001;1:103-32.

58. Hollister LE. Health aspects of cannabis. Pharmacol Rev 1986;38:1-20.

59. Rubino T, Vigano D, Massi P, Parolaro D. Changes in the cannabinoid receptor binding, G protein coupling, and cyclic AMP cascade in the CNS of rats tolerant to and dependent on the synthetic cannabinoid compound CP55,940. J Neurochem 2000;75:2080-6.
60. Georgotas A, Zeidenberg P. Observations on the effects of four weeks of heavy marihuana smoking on group interaction and individual behavior. Compr Psychiatry 1979;20:427-32.

61. Szabo B, Nordheim U, Niederhoffer N. Effects of cannabinoids on sympathetic and parasympathetic neuroeffector transmission in the rabbit heart. J Pharmacol Exp Ther 2001;297:819-26.

62. Mechoulam R, Shohami E, Fride E, Bab I. The ubiquitous role of endocannabinoids in physiological processes: examples in neuroprotection, feeding and bone formation. First European Workshop on Cannabinoid Research. Madrid (Spain) 2003;23:56-74.

63. Underner M, Urban T, Perriot J. Cannabis smoking and lung cancer. Int J Appl Pharm 2014;31:488-98.

64. De Petrocellis L, Melck D, Palmisano A, Bisogno T, Laezza C, Bifulco $\mathrm{M}$, et al. The endogenous cannabinoid anandamide inhibits human breast cancer cell proliferation. Proc Natl Acad Sci USA 1998;95:8375-80.

65. Shook JE, Burks TF. Psychoactive cannabinoids reduce gastrointestinal propulsion and motility in rodents. J Pharmacol Exp Ther 1989;249:444-9.

66. McCallum RW, Soykan I, Sridhar KR, Ricci DA, Lange RC, Plankey MW. Delta-9-tetrahydrocannabinol delays the gastric emptying of solid food in humans: a double-blind, randomized study. Aliment Pharmacol Ther 1999;13:77-80.

67. Coruzzi G, Adami M, Coppelli G, Frati P, Soldani G. Inhibitory effect of the cannabinoid receptor agonist WIN 55,212-2 on pentagastrin-induced gastric acid secretion in the anaesthetized rat. Naunyn Schmiedebergs Arch Pharmacol 1999;360:715-8.

68. Pate D. Glaucoma and cannabinoids. In: Grotenhermen F, Russo E. editors. Cannabis and cannabinoids. Pharmacology, toxicology, and therapeutic potential. Binghamton (NY): Haworth Press 2002;67:215-24.

69. Laine K, Jarvinen K, Jarvinen T. Topically administered CBreceptor agonist, JWH-133, does not decrease intraocular pressure (IOP) in normotensive rabbits. Life Sci 2003;72:83742.

70. Romero J, Garcia Palomero E, Castro JG, Garcia Gil L, Ramos JA, Fernandez Ruiz JJ. Effects of chronic exposure to $\Delta^{9}$ tetrahydrocannabinol on cannabinoid receptor binding and mRNA levels in several rat brain regions. Brain Res Mol Brain Res 1997;46:100-8.

71. Di Marzo V, Berrendero F, Bisogno T, Gonzalez S, Cavaliere P, Romero J, et al. Enhancement of anandamide formation in the limbic forebrain and reduction of endocannabinoid contents in the striatum of $\Delta^{9}$-tetrahydrocannabinol-tolerant rats. J Neurochem 2000;74:1627-35.

72. Jones RT, Benowitz N, Bachman J. Clinical studies of cannabis tolerance and dependence. Ann N Y Acad Sci 1976;282:221-39.

73. Benowitz NL, Jones RT. Cardiovascular effects of prolonged delta-9-tetrahydrocannabinol ingestion. Clin Pharmacol Ther 1975;18:287-97.

74. Wachtel SR, de Wit H. Naltrexone does not block the subjective effects of oral delta-tetrahydrocannabinol in humans. Drug Alcohol Depend 2000;59:251-60.

75. Haney M, Bisaga A, Foltin RW. Interaction between naltrexone and oral THC in heavy marijuana smokers. Psychopharmacology 2003;166:77-85.

76. Dora BN, Ganga RB, Raviteja B. Cytotoxicity activity of some indian medicinal plants. Int J Curr Pharm Res 2016;4:86-8. 